\title{
SMALL WHITE LADY'S-SLIPPER, Cypripedium candidum, COLLECTED IN SASKATCHEWAN IN 1895
}

\author{
BERNARD DE VRIES, 29 Hogan Place, Emerald Park, SK S4L 1C1
}

Small White Lady's-slipper, Cypripedium candidum Muhl. ex Willd., was collected once in Saskatchewan, in 1895, and there have been no additional records since that date. The 1895 specimen, now housed at the Department of Agriculture, Central Experimental Farm, Ottawa (DAO) is labeled: "Ex Herb. Central Experimental Farm, Ottawa, Canada; Cypripedium candidum Muhl.; Indian Head, Assa.; D. Macoun, 18701/2, June 1895." This is the collection on which Maher et al. and Scoggan based their reports of Small White Lady's-slipper occurring at Indian Head in south-eastern Saskatchewan. ${ }^{7,8}$ This early and only collection for Saskatchewan is of significant botanical and historical interest, especially to those involved with documenting rare and endangered species.

The collector, David Macoun, was the nephew of John Macoun, naturalist to the Geological and Natural History Survey of Canada, and accompanied him in exploratory expeditions on the Canadian Prairies during the summers of 1879,1880 , and 1881. At the close of the 1881 season, David Macoun remained in the west, and in 1883 filed on a homestead on SE6-20-11-W2, south of Balcarres, which is north of the Qu'Appelle valley and approximately $30 \mathrm{~km}$ northeast of Indian Head. ${ }^{5,6}$ David Macoun was employed as foreman in residence at the newly established Experimental Farm south of Indian Head from 1884 to 1903. It was during this period, in
1895, that Small White Lady's-slipper was collected.

The exact collection location of the 1895 Small White Lady's-slipper specimen is unknown. The fact that $D$. Macoun was at Indian Head suggests the possibility that this orchid could have been collected in the Strawberry Lakes area about $15 \mathrm{~km}$ southwest of Indian Head. This area has some open moist prairies and marshes which are an ecological requirement for this orchid. ${ }^{1,3}$

Hudson suggested that the collection could have been made in the Qu'Appelle valley, which David Macoun would have had to cross in traveling between his homestead and Indian Head. ${ }^{4}$ Along the south banks of this valley, there are several ravines with ground water seepages that could offer suitable habitat for this orchid. The 1895 record appears to be the only plant collection attributed to David Macoun, since no other collections by him could be located, and this collection of Small White Lady's-slipper could have been a chance occurrence.

The possibility that the Indian Head specimen was based on a plant transplanted to the Experimental Farm seems remote. No records exist that this orchid was grown at the Experimental Station (G. R. Boughton, Superintendent, pers. comm., 1987).

In spite of dramatic changes to the landscape in south-central and eastern 


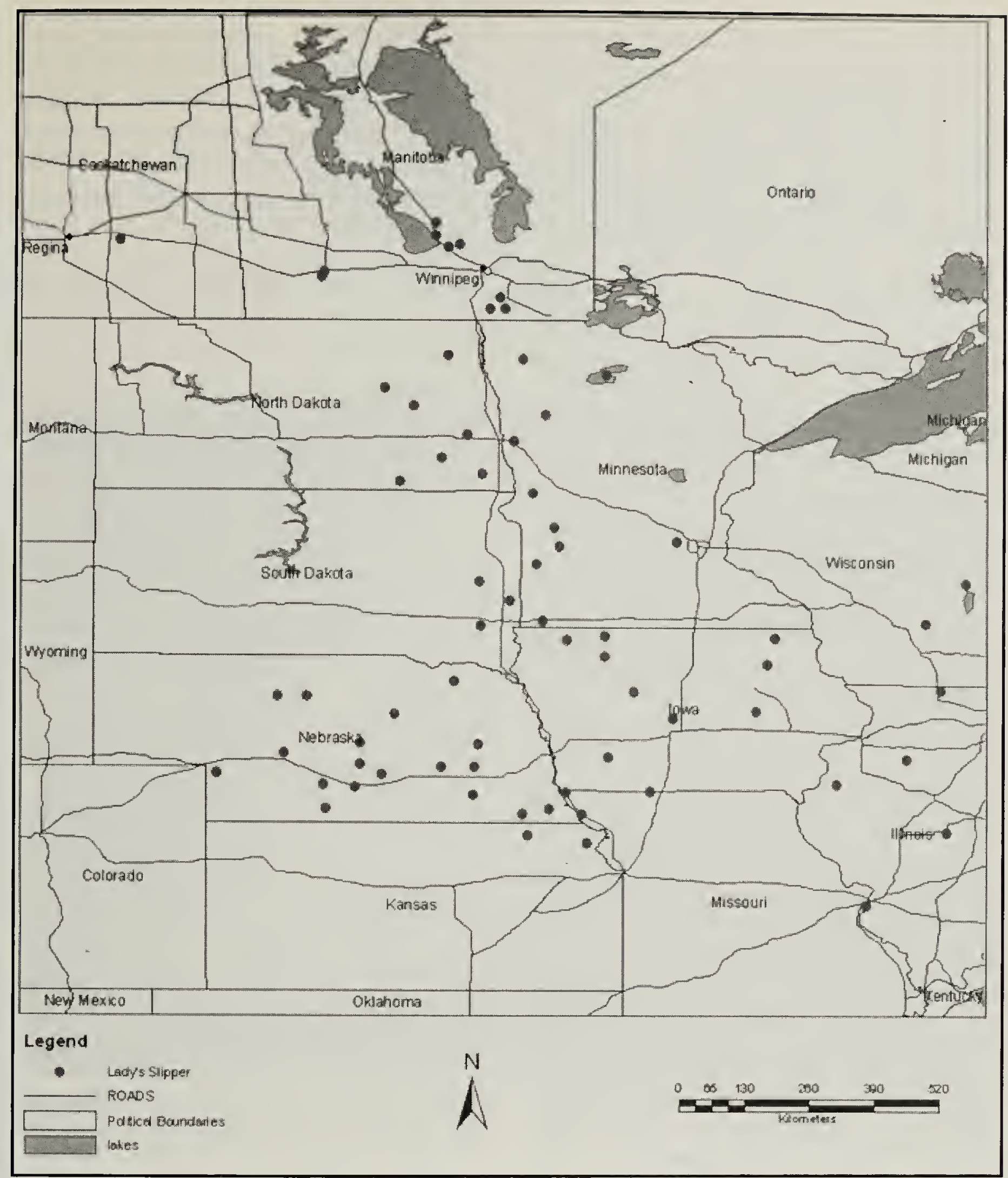

Figure 1. Distribution of Small White Lady's-slipper in western North America.

Saskatchewan, the remote possibility exists that the species could have survived in some isolated remnant of its original habitat in the south-east area of the province. However, since no other records of this orchid were made between 1895 and the present, it is more likely that the species is 'extirpated' in Saskatchewan.

This orchid is found throughout the eastern tall grass prairie, with the main geographic distribution in eastern North and South Dakota, Nebraska, western Minnesota and lowa, and southeastern Manitoba (Figure 1). In Manitoba, this species was first reported near Brandon and Aweme by Fletcher (1889), and J.M. Macoun (1903), (A. Breitung, pers. comm., 1986). A later discovery of this orchid was southwest of Brandon some 240 $\mathrm{km}$ east of Indian Head (A. Rogosin, Curator Herbarium, University of 
Brandon, Manitoba, pers. comm., 1986). Further Manitoba discoveries were south of Steinbach, northwest of Winnipeg in the Warren-Oak Point area, and Tall Grass Prairie Preserve, Tolstoi to Gardenton, St. Laurent, Lake Francis, Brandon, Woodlands, Kleefield, Treherne, and Pembina Hills. ${ }^{2}$ From this distribution pattern, it would appear that this orchid was at its western, as well as northern, range limit in Saskatchewan; a factor affecting its vulnerability to habitat changes.

\section{Acknowledgements}

Special thanks are extended to the late A.J. Breitung whose interests in the flora of Saskatchewan led to this particular orchid and prompted research into its fascinating history; J.H. Hudson, Saskatoon; W.J. Cody, Department of Agriculture, Ottawa; G. Argus, National Museums of Canada, Ottawa; M. Shchepanek, Botany Division, National Museums of Canada, Ottawa; G.R. Boughton, Experimental Farm, Indian Head; J.A.G. Howe, Tree Nursery Division, Indian Head; and the staff of the Saskatchewan Archives Board and Land Titles Offices, Regina, for their valuable help in providing information and locating documents necessary for this paper. Thanks are also due to Steve Porter, Data Manager for the
Saskatchewan Conservation Data Centre, Resource Stewardship Branch, Saskatchewan Environment, Regina who prepared the distribution map, based on range maps for this orchid in "Handbook of North Dakota Plants and Species At Risk."

1. BUDD, A.C. 1979. Budd's Flora of the Canadian Prairie Provinces. Research Branch Agriculture Canada, Publication 1662.

2. COSEWIC, in Press. COSEWIC Assessment and Update Status Report on the Small White Lady's-slipper Cypripedium candidum in Canada. Committee on the Status of Endangered Wildlife in Canada. Ottawa.

3. HARMS, V.L. 2003. Checklist of the Vascular Plants of Saskatchewan and the Provincially and Nationally Rare Native Plants in Saskatchewan. University of Extension Press, University of Saskatchewan, Saskatoon.

4. HUDSON, J. 2005. Further to the Small White Lady's Slipper. Letter to Nature Views, Nature Saskatchewan, Fall Issue.

5. MACOUN, J. 1903. Contribution to Canadian Botany. Ottawa Field Naturalist 16(11):221

6. MACOUN, J. 1922. Autobiography of John Macoun, M.A. The Ottawa Field-naturalists' Club.

7. MAHER, R.V., G.W. ARGUS, V.L. HARMS, and J.H. HUDSON. 1979. The Rare Vascular Plants of Saskatchewan. Syllogeus 20. National Museums of Canada, Ottawa.

8. SCOGGAN, H.J. 1978. The Flora of Canada, Part 2. National Museums of Natural Sciences. 91-545.

"Moths had a head start [over butterflies] on floral relationships, as fossil evidence shows that moths are many millions of years older than butterflies. This helps explain why moth pollination is far more common and variable in nature than is butterfly pollination." Peter Bernhardt, The Rose's Kiss: A Natural History of Flowers, p.151 